\author{
A.R. Yeshkeyev, A.K. Issaeva, N.V. Popova \\ Ye.A. Buketov Karaganda State University, Kazakhstan \\ (E-mail: isa_aiga@mail.ru)
}

\title{
Closure of special atomic subsets of semantic model
}

\begin{abstract}
The present paper concerns some properties of the so-called small models, generally speaking, not necessarily complete theories and their relationship with each other. In the well-known paper [1], R. Vaught have proved the fundamental theorem-criterion on the behavior of countable prime and atomic models for complete theories in countable language. The essence of this criterionis that in a complete theory any countable prime model is at the same time an atomic model of this theory. The result obtained in this paper is related to the classical problem of Vaught about countably prime models of complete theories but in more general formulation of the notion of countable atomicity. The main result of this paper is that it focuses on the syntactic properties on special subsets of a fragment of the semantic model the specific Jonsson theory. The concept of the so-called model-theoretic «rheostat» was also used to obtain results related to the refinement of the concept of atomicity in the framework of Jonsson's theories.
\end{abstract}

Keywords: Jonsson theory, semantic model, existentially prime model, atomic model, core model.

In [1] it was proved that the atomic model is countable prime. In model theory, small models are countable models with additional conditions, in particular, prime or atomic ones. Moreover, if a theory has a countable atomic model, then it is unique up to isomorphism. The atomicity criterion for the models obtained by Vaught was proved in the framework of the study of complete theories. Thus, if we are dealing with complete theories, then any theory that has a simple model has a good syntactic characteristic, namely, any element of this model implements some basic type. We will have a different situation if we investigate a more general picture: we omit the condition of completeness. In this case, instead of a prime model, the concept of an algebraically prime model is usually considered. Much has been done in this direction in [2]. But, as the results of this work showed, the criterion of small models in the framework of the study of the concepts of atomicity or algebraic primarily in [2] was not obtained. Moreover, for all kinds of atomic models that were considered in this work, examples of those theories that did not even have an algebraically prime model were built.

In connection with this dissonance between atomicity and algebraic primarily, we continue to search for additional conditions which will make it possible to find an analog of the main result from [1] for the corresponding primarily of simplicity and atomicity for models of theories considered.

In this article, we will focus our attention on the study of special models for certain types of Johnson theory within the framework of the above topics [6-8]. To have an idea of previous works concerning the behavior of small models in Jonsson's theories, the following sources can be used: [4, 5]. One of the central ideas that allow us to compare the concepts of atomicity in the sense of [1] and in the sense of [2] is the idea concept of «rheostat» [4, $5]$. It is clear that the larger the Johnson set, the closer the model considered to atomicity from [2] and, conversely, the smaller it is, the closer to the notion of atomicity from [1]. We fix some Johnson theory $T$ and its semantic model $C$. All sets considered in this article will be subsets of this semantic model. The fragments considered should not preserve the model-theoretical properties of the fixed Jonsson theory described above. Therefore, in each case, we will stipulate certain model-theoretical conditions under which the current problem will be considered.

Consider the necessary definitions of concepts and their properties.

Definition 1. The theory of $T$ is Jonson theory if:

1) the theory $T$ has infinite models;

2) the theory $T$ is inductive theory;

3 ) the theory $T$ has the joint embedding property $(J E P)$;

4 ) the theory $T$ has the property of amalgam $(A P)$.

The following definition of the universality and homogeneity of a model identifies the semantic invariant of any Jonsson theory, namely its semantic model. Moreover, it turned out that the saturation or unsaturation of this model significantly changes the structural properties of both Jonsson's theory and its class of models. 
Definition 2. [8] Let $\kappa \geq \omega$. A model $M$ of theory $T$ is called a $\kappa$-universal for $T$ if every model of $T$ with degree strictly less than $\kappa$ is isomorphically embedded into $M ; \kappa$-homogeneous for $T$, if for any two models $A$ and $A_{1}$ of theory $T$, which are submodels of $M$ with the power strictly less then $\kappa$ and for isomorphism $f: A \rightarrow A_{1}$ for each extension $B$ of model $A$, which is a submodel of $M$ and is a model of $T$ with the power strictly less then $\kappa$ there is the extension $B_{1}$ of model $A_{1}$, which is a submodel of $M$ and an isomorphism $g: B \rightarrow B_{1}$ which extends $f$.

$\kappa$ is homogeneous for $T$ if, for any two models $A$ and $A_{1}$ of $T$, which are submodels of $M$ with power strictly less than $\kappa$, and for the isomorphism $f: A \rightarrow A_{1}$ for each extension $B$ of model $A$, which is a submodel of $M$ and is a model of theory $T$ with power strictly less than $\kappa$, there is an extension $B_{1}$ of model $A_{1}$, which is a submodel of $M$ and the isomorphism $g: B \rightarrow B_{1}$, which extends $f$.

Definition 3. [9] We say model $C$ of Jonsson theory $T$ is called semantic model when it is $\omega^{+}$-homogeneousuniversal.

In accordance with the definition of the concept of Jonsson theory, it is clear that this theory is not complete. But, nevertheless, given its semantic invariant (semantic model), we can always determine the center of Jonsson's theory, which is a complete theory.

Definition 4. [7] The center of Jonsson's theory $T$ is called the elementary theory of its semantic model. And is denoted by $T^{*}$, i.e. $T^{*}=T h(C)$.

The «good» exclusivity of the semantic model can be judged by the following facts.

Fact 1. Each Jonsson theory $T$ has $k^{+}$-homogeneous-universal model of power $2^{k}$. Conversely, if the theory $T$ is inductive and has infinite model and $\omega^{+}$-homogeneous-universal model then the theory $T$ is a Jonsson theory.

Fact 2. Let $T$ be Jonsson theory then two $k$-homogeneous-universal models $M$ and $M_{1}$ of $T$ are elementary equivalent.

Definition 5. Jonsson theory $T$ is called a perfect theory if each a semantic model of theory $T$ is saturated model of $T^{*}$.

A result describing the perfect Jonsson theory introduced by A.R. Yeshkeyev [7].

Theorem 1. Let $T$ be Jonsson's theory. We conclude that the following conditions are equivalent:

1) Theory $T$ is perfect;

2) Theory $T^{*}$ is a model companion of theory $T$.

Let $E_{T}$ be the class of all existentially closed models of the Johnson theory $T$. In the general case, this class of models for an arbitrary theory may be empty. Given the well-known result of work [4], we can say that any inductive theory has a non-empty class of existentially closed models. Since Jonsson's theory is a subclass of the class of inductive theories, we can say that $E_{T}$ is a non-empty class.

In the case of the perfect Johnson theory, the class model center of this theory coincides with $E_{T}$, which follows from Theorem 2 .

Theorem 2. If $T$ is a perfect Jonsson theory then $E_{T}=\operatorname{Mod} T^{*}$.

Let $L$ is a countable language of the first order. Let $T$ is Jonsson's theory in the language $L$ and its semantic model is $\mathcal{C}$.

We give important definitions related to the concept of the atomic set $\left(\nabla_{1}, \nabla_{2}\right)-c l$ being the central concept of this article

Let $C$ be a semantic model of some Jonsson theory $T$ in a fixed language.

Definition 6. [6] Model $A$ of a theory $T$ is called existentially closed if for any model $B$ and any existential formula $\varphi(\bar{x})$ with constants of $A$ we have $A \models \exists \bar{x} \varphi(\bar{x})$ provided that $A$ is a submodel of $B$ and $B \models \exists \bar{x} \varphi(\bar{x})$.

Definition \%. Let $A$ be a model of $T$ and $A$ can be isomorphically embedded into each model of theory $T$, then $A$ is an algebraically simple model of theory $T$.

Definition 8 . The inductive theory $T$ is called the existentially prime if:

1) it has an algebraically prime model, the class of its $A P$ (algebraically prime models) denote by $A P_{T}$;

2) class $E_{T}$ non-trivial intersects with class $A P_{T}$, i.e. $A P_{T} \bigcap E_{T} \neq 0$.

Definition 9.A model $A$ is called atomic in meaning work [1] if every tuple of its elements satisfies some complete formula.

Definition 10. [2] A formula $\varphi(\bar{x})$ is a $\Delta$-formula, if exist existential formulas (from $\Sigma) \psi_{1}(\bar{x})$ and $\psi_{2}(\bar{x})$ such that

$$
T \models\left(\varphi \leftrightarrow \psi_{1}\right) \quad \text { и } \quad T \models\left(\neg \varphi \leftrightarrow \psi_{2}\right)
$$




\section{Definition 11}

(i) $\left(A, a_{0}, \ldots, a_{n-1}\right) \Rightarrow_{\Gamma}\left(B, b_{0}, \ldots, b_{n-1}\right)$ means that for every formula $\varphi\left(x_{1}, \ldots, x_{n-1}\right)$ of $\Gamma$, if $A \models \varphi(\bar{a})$, then $B=\varphi(\bar{b})$.

(ii) $(A, \bar{a}) \equiv_{\Gamma}(B, \bar{b})$ means that $(A, \bar{a}) \Rightarrow_{\Gamma}(B, \bar{b})$ and $(B, \bar{b}) \Rightarrow_{\Gamma}(A, \bar{a})$.

As classes $\Gamma$ we consider $\triangle$ or $\Sigma$.

Consider a complete theory $T$ in $L$. A formula $\varphi\left(x_{1} \ldots x_{n}\right)$ is said to be complete (in $T$ ) iff for every formula $\psi\left(x_{1} \ldots x_{n}\right)$ exactly one of

$$
T \models \varphi \rightarrow \psi, \quad T \models \varphi \rightarrow \neg \psi
$$

holds. A formula $\theta\left(x_{1} \ldots x_{n}\right)$ is said to be completable (in $T$ ) if and only if there is a complete formula $\varphi\left(x_{1} \ldots x_{n}\right)$ with $T \models \varphi \rightarrow \theta$. If $\theta\left(x_{1} \ldots x_{n}\right)$ is not completable it is said to be incompleatable.

A theory $T$ is said to be atomic iff every formula of $L$ which is consistent with $T$ is completable in $T$. A model $A$ is said to be an atomic model iff every $n$ - tuple $a_{1} \ldots a_{n} \in A$ satisfies a complete formula in $T h(A)$

In connection with the new concept of atomicity from [2], we conclude that the following concept will be similar to the definition of the full formula.

Definition 12. A formula $\varphi\left(x_{1}, \ldots, x_{n}\right)$ is complete for $\Gamma$-formulas(w.r.t T) if $\varphi$ is consistent with $T$ and for every formula $\psi\left(x_{1}, \ldots, x_{n}\right)$ in $\Gamma$, having no more free variables than $\varphi$, either

\section{$T \vDash \forall \bar{x}(\varphi \rightarrow \psi)$ or $T \vDash \forall \forall \bar{x}(\varphi \rightarrow \neg \psi)$.}

Equivalently, a consistent $\varphi(\bar{x})$ is complete for $\Gamma$-formulas provided whenever as $\psi(\bar{x})$ is a $\Gamma$ - formula and $(\varphi \wedge \psi)$ is consistent with $T$, then $T \models(\varphi \rightarrow \psi)$.

And the concept of the atomic model from [2] is transformed into the following concept from next the definitions

Definition 13. Let $B$ be $\left(\Gamma_{1}, \Gamma_{2},\right)$ - an atomic model of $T$, if $B$ is a model of $T$ and for every $n$ every $n$-tuple of elements of $A$ satisfies some formula from $B$ in $\Gamma_{1}$, which is complete for $\Gamma_{2}$-formulas.

A generalization of the above definition is the definition of a weakly atomic model from [2].

Definition 14. $B$ is weak $\left(\Gamma_{1}, \Gamma_{2}\right)$ - atomic model of $T$, if $B$ is a model of $T$ and for every $n$ every $n$-tuple $\bar{a}$ a of elements of $A$ satisfies in $B$ some formula $\varphi(\bar{x})$ of $\Gamma_{1}$ such that $T \models(\varphi \rightarrow \psi)$ as soon as $\psi(\bar{x})$ of $\Gamma_{2}$ and $B \models \psi(\bar{a})$.

Presenting sufficient number of examples given in [2] of this article, we will not give examples of the $\left(\Gamma_{1}, \Gamma_{2}\right)$ - atomic model and the weak $\left(\Gamma_{1}, \Gamma_{2}\right)$ atomic model, leaving the reader the opportunity to review them independently.

Next, we examine the special types of sets that we will deal with.

Let $c l$ be some closure operator that defines pregeometry over $C$ (for example, $c l=a c l$ or $c l=d c l$ ). It is certain that such an operator is a special case of the closure operator, and its example is the closure operator, defined on any linear space as a linear hull.

Before discussing the results obtained, concerning $\left(\nabla_{1}, \nabla_{2}\right)-c l$ atomic models, we note that we fix some Jonsson theory $T$ and its semantic model $C$ in the countable language $L$ and $\nabla_{1}, \nabla_{2} \subseteq L:\left(\nabla_{1}, \nabla_{2}\right)$. Actually those sets consists of $\exists, \forall, \forall \exists$-formulas which are consistent with $T$, that is, any finite subset of formulas from $\nabla_{1}, \nabla_{2}$ are consistent with $T$. Let $A \subseteq C$.

Definition 15. [4] The set $A$ is called $\left(\nabla_{1}, \nabla_{2}\right)-c l$ atomic in the theory $T$, if

1) $\forall a \in A, \exists \varphi \in \nabla_{1}$ such that for any formula $\psi \in \nabla_{2}$ follows that $\varphi$ is a complete formula for $\psi$ and $C \models \varphi(a)$

2) $c l(A)=M, M \in E_{T}$,

and obtained model $M$ is said to be $\left(\nabla_{1}, \nabla_{2}\right)-c l$ atomic model of theory $T$.

Definition 16. [4] The set $A$ is called weakly $\left(\nabla_{1}, \nabla_{2}\right)-c l$ is atomic in $T$, if

1) $\forall a \in A, \exists \varphi \in \nabla_{1}$ such that in $C \models \varphi(a)$ for any formula $\psi \in \nabla_{2}$ follow that $T \models(\varphi \rightarrow \psi)$ whenever $\psi(x)$ of $\nabla_{2}$ and $C \models \psi(a)$;

2) $c l(A)=M, M \in E_{T}$,

and obtained model $M$ is said to be weakly $\left(\nabla_{1}, \nabla_{2}\right)-c l$ atomic model of theory $T$.

It is easy to understand that definitions 18 and 19 are naturally generalized the notion of atomicity and weak atomicity to be $\nabla_{1}$-atom and weak $\nabla_{1}$-atom for any tuple of finite length from set $A$.

Let $i \in\{1,2\}, M_{i}=c l\left(A_{i}\right)$, where $A_{i}=\left(\nabla_{1}, \nabla_{2}\right)$ is a $c l-$ atomic set. $a_{0}, \ldots, a_{n-1} \in A_{1}, b_{0}, \ldots, b_{n-1} \in A_{2}$.

Definition 1\%. [4]

(i) $\left(M_{1}, a_{0}, \ldots, a_{n-1}\right) \Rightarrow \nabla\left(M_{2}, b_{0}, \ldots, b_{n-1}\right)$ means that for every formula $\varphi\left(x_{1}, \ldots, x_{n-1}\right)$ of $\nabla$, if $M_{1} \models \varphi(\bar{a})$, then $M_{2} \models \varphi(\bar{b})$. 
(ii) $\left(M_{1}, \bar{a}\right) \equiv_{\nabla}\left(M_{2}, \bar{b}\right)$ means that $\left(M_{1}, \bar{a}\right) \Rightarrow_{\nabla}\left(M_{2}, \bar{b}\right)$ and $\left(M_{1}, \bar{b}\right) \Rightarrow_{\nabla}\left(M_{1}, \bar{a}\right)$.

Definition 18. [4] A set $A$ will be called $\left(\nabla_{1}, \nabla_{2}\right)$ - cl-algebraically prime in the theory $T$, if

1) If $A$ is $\left(\nabla_{1}, \nabla_{2}\right)-c l$-atomic set in $T$;

2) $\operatorname{cl}(A)=M, M \in A P_{T}$,

and obtained model $M$ is said to be $\left(\nabla_{1}, \nabla_{2}\right)-c l$ algebraically prime model of theory $T$.

From the definition of an algebraically prime set in the theory $T$ follows that the Jonsson theory $T$ which has an algebraically prime set is automatically existentially prime. It is easy to understand that an example of such a theory is the theory of linear spaces.

Recall that the model $A$ of theory $T$ is called core if it is isomorphically embedded in any model of a given theory and this isomorphism exactly one.

Definition 19. [4] The set $A$ will be called $\left(\nabla_{1}, \nabla_{2}\right)-c l$-core in the theory $T$, if

1) $A$ is $\left(\nabla_{1}, \nabla_{2}\right)$ a $c l$ - atomic set in the theory $T$;

2) $\operatorname{cl}(A)=M$, where $M$ is a core model of theory $T$

and obtained model $M$ is said to be $\left(\nabla_{1}, \nabla_{2}\right)-c l$ core model of theory $T$.

Definition 20. [5] (a) A - $\left(\nabla_{1}, \nabla_{2}\right)-c l$-atomic set in theory $T$ is said to be A - $\left(\nabla_{1}, \nabla_{2}\right)-c l$ - $\Sigma$-nice-set in theory $T, \forall A^{\prime}: A^{\prime}-\left(\nabla_{1}, \nabla_{2}\right)-c l$-atomic set in theory $T$, if

1) $\operatorname{cl}(A)=M \in E_{T} \cap A P_{T}$,

and obtained model $M$ is said to be $\left(\nabla_{1}, \nabla_{2}\right)-c l$ - $\Sigma$-nice model of theory $T$.

2) for all $a_{0}, \ldots, a_{n-1} \in A, b_{0}, \ldots, b_{n-1} \in A^{\prime}$, if $\left(M, a_{0}, \ldots, a_{n-1}\right) \Rightarrow \exists\left(M^{\prime}, b_{0}, \ldots, b_{n-1}\right)$, then $\forall a_{n} \in A, \exists b_{n} \in A^{\prime}$ such that $\left(M, a_{0}, \ldots, a_{n}\right) \Rightarrow_{\exists}\left(M^{\prime}, b_{0}, \ldots, b_{n}\right)$, where $M^{\prime}=\operatorname{cl}\left(A^{\prime}\right)$.

(b) $A-\left(\nabla_{1}, \nabla_{2}\right)-c l-\Sigma^{*}$-nice-set in theory $T$ if the condition in (a) holds with ' $\Rightarrow \exists$ ' replaced both places it occurs by ' $\equiv \exists$ ' and obtained model $M$ is said to be $\left(\nabla_{1}, \nabla_{2}\right)-c l$ - $\Sigma^{*}$-nice model of theory $T$.

(c) $A-\left(\nabla_{1}, \nabla_{2}\right)-c l-\Delta$-nice set in theory $T$ if the condition in (a) holds with ' $\Rightarrow_{\Delta}$ ' replaced both places it occurs by '” $\equiv_{\Delta}$ ', where $\Delta \subseteq L, \Delta=\forall \cap \exists$.

and obtained model $M$ is said to be $\left(\nabla_{1}, \nabla_{2}\right)-c l-\Delta$-nice model of theory $T$.

Theorem 3. [5] Let $T$ be complete for $\exists$-sentences a strongly convex Jonsson perfect theory and let $M$ is $\left(\nabla_{1}, \nabla_{2}\right)-c l$-atomic model in $T$.

(a) Then $(i) \Rightarrow(i i) \Rightarrow($ iii $)$ and $(i i) \Rightarrow(i i)^{*}$ where:

(i) $M$ is $(\Sigma, \Sigma)-c l$-atomic model in theory $T$,

(ii) $M$ is $\left(\nabla_{1}, \nabla_{2}\right)-c l$ - $\Sigma^{*}$-nice-model in theory $T$,

(ii)* $M$ is e.c. and $\left(\nabla_{1}, \nabla_{2}\right)-c l-\Sigma$-nice model in theory $T$,

(iii) $M$ is weak $(\Sigma, \Pi)-c l$-atomic model in theory $T$,

(b) If $T$ is complete for $\forall \exists$ sentences, then $(i),(i i),(i i)^{*}$ and (iii) are all equivalent.

Principle of «rheostat». [5]

Let two countable models $A_{1}, A_{2}$ of some Jonsson theory $T$ be given. Moreover, $A_{1}$ is an atomic model in the sense of [1], and $X$ is $\left(\nabla_{1}, \nabla_{2}\right)-c l$-algebraically prime set of theory $T$ and $\operatorname{cl}(X)=A_{2}$. Since $\nabla_{1}=\nabla_{2}=L$, then $A_{1} \cong A_{2}$.

By the definition of $\left(\nabla_{1}, \nabla_{2}\right)$ - algebraic primeness of the set $X$, the model $A_{2}$ is both existentially closed and algebraically prime. Thus, the model $A_{2}$ is isomorphically embedded in the model $A_{1}$. Since by condition the model $A_{1}$ is countably atomic, then according to the Vaught's theorem, $A_{1}$ is prime, i.e. it is elementarily embedded in the model $A_{2}$. Thus, the models $A_{1}, A_{2}$ differ from each other only by the interior of the set $X$. This follows from the fact that any element of $a \in A_{2} \backslash X$ implements some main type, since $a \in \operatorname{cl}(X)$. That is, all countable atomic models in the sense of [1] are isomorphic to each other, then by increasing $X$ we find more elements that do not realize the main type and, accordingly, $\operatorname{cl}(X)$ is not an atomic model in the sense of [1]. Thus, the principle of rheostat is that, by increasing the power of the set $X$, we move away from the notion of atomicity in the sense of [1] and on the contrary, decreasing the power of the set $X$ we move away from the notion of atomicity in the sense of [2].

Let $A P C \in\{$ atomic, algebraically prime, core $\}$. Thus, by specifying the set $X$ as $\left(\nabla_{1}, \nabla_{2}\right)-c l-A P C$, (where $A P C$ is a semantic property), we can also specify atomicity in the sense [2] in relation to atomicity in the sense of [1]. And accordingly, according to the principle of «rheostat» after the $A P C$ property is defined, we obtain the corresponding concepts of atomic models, the role of which is played $A_{2}$ from the principle of «rheostat».

Let us consider some properties of the types of models described above and their connection with some properties concerning the syntactic characteristics of a certain «atomicity» of existential formulas. We introduce some properties from [2], denoted by $\left(R_{0}\right)$ and $\left(R_{1}\right)$, the essence of these properties is as follows:

$\left(R_{0}\right)$ : Every existential formula complete for $\Delta$ formulas is complete for existential formulas. 
$\left(R_{1}\right)$ : Every existential formula $\varphi(\bar{x})$ consistent with $T$ is implied by some $\Delta$ formula $\left.\theta(\bar{x})\right)$ consistent with $T$.

We will say that Jonsson's theory admits $\left(R_{0}\right)$ and $\left(R_{1}\right)$ if these conditions are satisfied for all the corresponding forms of formulas compatible with the theory $T$.

The following results characterize properties of $\left(R_{0}\right)$ and $\left(R_{1}\right)$. To prove Theorem 4 , we need auxiliary lemmas. Let us give them

We will call $X$ a subset of the semantic model $C$ of the above fixed Jonsson theory $T$. Then the fragment $F$ of set $X$ is the set of all universally existential sentences true in the definable closure of this set $X$. That is, $F=T h_{\forall \exists}(\operatorname{cl}(X))$, where $c l=d c l d c l(X)=M M \in M o d E_{T}$, as well as $M$ satisfies the same conditions as the set $X$.

Lemma 1. Let $F$ be some fragment $\left(\nabla_{1}, \nabla_{2}\right)-c l-\Delta$-nice a.p. set of $X . F$ - is a perfect existentially prime complete theory for $\exists$-sentences. Then fragment $F$ entails property $\left(R_{1}\right)$

By of perfectness, all formulas with respect to the $F^{*}$ - center of the theory $F$, due to the model completeness of $F^{*}$ and the existential simplicity of the theory $F$, we can assume that it suffices to consider the case when $\left(\nabla_{1}=\nabla_{2}\right)$ and equals $(\nabla)$.

Proof. Let $A$ be a $\left(\nabla_{1}, \nabla_{2}\right)-c l-\Delta$-nice a.p. model of theory $F$ and let $\varphi(\bar{x})$ be an existential formula consistent with $F$. Then $A=\varphi(\bar{a})$ for some $(\bar{a})$ in $A$. Let $\left\{\theta_{i}(\bar{x}): i \in \omega\right\}$ be the set of all $\Delta$ satisfied by $(\bar{a})$ in $A$. By $\left(\nabla_{1}, \nabla_{2}\right)-\Delta-$ nicenessa.p, if $B$ is a model of $F$ and $B=\theta(\bar{b})$ for all $i \in \omega$, then $\left(A,(\bar{a}) \equiv_{\Delta}(B,(\bar{b}))\right.$ and so $A$ can be embedded in $B$ with each $a_{i}$ mapped to $b_{i}$. Hence $B \models \varphi(\bar{b})$ since $\varphi$ is existential. Therefore, $\varphi$ follows from $\theta_{i}: i \in \omega$ on models of $F$. By compactness, we get a single $\Delta$ formula $\theta(\bar{x})$ satisfied by $(\bar{a})$ and such that $F \models(\theta \rightarrow \varphi(\bar{a}))$, and so this fragment $F$ admits property $R_{1}$.

Lemma 2. Let $F$ be some fragment $\left(\nabla_{1}, \nabla_{2}\right)-c l-\Delta-$ nice a.p. set of $X$. $F$ - is a perfect existentially prime complete theory for $\exists$-sentences. Then $R_{1}$ entails $R_{0}$.

Proof. By virtue of Lemma1 $F$ admits the $R_{1}$ property. By virtue of the perfection of the theory $F$ and the model completeness of $F^{*}$ without loss of generality, we can assume that there exists a $\Delta$ formula $\theta(\bar{x})$ compatible with $F$ such that $F \models \theta \rightarrow(\varphi \wedge \psi)$, where $(\varphi \wedge \psi)$ is shared with $F$. Then $F \models(\varphi \rightarrow \theta)$ since $\varphi$ is complete for $\Delta$ formulas and $\varphi \wedge \theta$ is consistent with $F$. Hence $F=(\varphi \rightarrow \psi)$.

Therefore $\varphi$ is complete for existential formulas. Thus, $R_{0}$ is satisfied.

We proceed directly to the proof of the following theorem.

Theorem 4. Let $F$ be some fragment $\left(\nabla_{1}, \nabla_{2}\right)-c l-\Delta-$ nice algebraically prime set $X$ and let $A \in A P_{F} \cap E_{F}$ from the fragment $F$ is a perfect existentially prime theory, complete for $\exists$ - sentences. Then $A$ is $\left(\nabla_{1}, \nabla_{2}\right)-\Delta-$ nice algebraically prime set if and only if $A$ is $\left(\nabla_{1}, \nabla_{2}\right)-c l-\Delta-$ nice - atomic.

Let $F$ be some fragment $\left(\nabla_{1}, \nabla_{2}\right)-c l-\Delta-$ nice algebraically prime set $X$ and let $A \in A P_{F} \cap E_{F}$ and $F$ fragment is a complete existentially simple theory, complete for $\exists$ - sentences. Then $A$ is $\left(\nabla_{1}, \nabla_{2}\right)-\Delta-n i c e$ algebraically prime if and only if $A$ is $\left(\nabla_{1}, \nabla_{2}\right)-c l-\Delta$ - nice - atomic.

Let $T$ be an $\forall \exists$ theory complete for existential sentences, and let $A$ be a countable model of $T$. Then $A$ is $\triangle$-nice if and only if $A$ is $(\triangle, \Sigma)$-atomic.

Proof Suppose $A$ is $\left(\nabla_{1}, \nabla_{2}\right)-c l-\Delta-$ nice - atomic. Then, from the same proof of an isomorphism of the corresponding countable models by Theorem 4[5] and Theorem 3 (the proof of which can be found in the work of "Core Jonsson theories"in this volume) it follows that $A$ is $\left(\nabla_{1}, \nabla_{2}\right)-c l-\Delta-$ nice. The rest follows from the perfection of the fragment $F$ and the model completeness of $F^{*}$.

Next, we prove in the opposite direction. Suppose $A$ is $\left(\nabla_{1}, \nabla_{2}\right)-c l-\Delta-$ nice. Then $\left(R_{1}\right)$ holds by Lemma 1 and also $\left(R_{0}\right)$ by Lemma 2 . Since $A$ is in a particularly algebraically prime and existentially closed model of $F$, we know that $F$ has $\left(\nabla_{1}, \nabla_{2}\right)-c l-\Delta-$ nice- atomic model.

Therefore by Theorem 4 [5] every existential formula $\psi(\bar{x})$ consistent with $F$ is implied by an existential formula $\varphi(\bar{x})$ complete for $(\Delta)$-formulas. By $\left(R_{0}\right)$ is, in fact, complete for existential formulas. By $\left(R_{1}\right)$ there is a $(\Delta)$ formula $\theta(\bar{x})$ consistent with $F$ such that $F \models(\theta \rightarrow \varphi)$. Then $\theta$ is also complete for existential formulas and $F \models(\theta \rightarrow \psi)$. So by Theorem 4 [5] $T$ has a $\left(\nabla_{1}, \nabla_{2}\right)-c l-\Delta-$ nice- atomic model. By Theorem 2[4] $F$ can have only one a.p. model, so the given a.p. model $A$ must be $\left(\nabla_{1}, \nabla_{2}\right)-c l-\Delta-$ nice--atomic.

Theorem 5. Let $F$ be a convex perfect existentially simple complete fragment for $\exists$ sentences of some $\left(\nabla_{1}, \nabla_{2}\right)-c l-\Delta-$ nice - set $X$ Then the following are equivalent:

(i) $F^{*}$ has a core model;

(ii) whenever $\psi(x)$ is existential and $F \models \exists x \psi$, then there is some existential $\varphi(x)$ and integer $k$ such that

$$
F \models\left(\exists^{=k}\right) x \varphi \wedge \exists(x)(\varphi \wedge \psi),
$$

and $(\#)$ if $F \models\left(\sigma_{1} \vee \sigma_{2}\right)$ where $\sigma_{1}, \sigma_{2}$ are existential sentences, then $F \models \sigma_{1}$ or $\left.F \models \sigma_{2}\right)$. 
Proof. Since $F$ is perfect and convex, it has a unique core model that will be the core model and its center. Therefore, from (1) in (2) follows from Theorem 3 (the proof of which can be found in the work of «Core Jonsson theories» in this volume).

The proof in the opposite direction follows from the fact that Let $F^{*}$ be the center of $F$, then the Kaiser shell $F$ coincides with $F^{*}$ by virtue of perfection, and the Kaiser shell is $F^{0}=T h_{\forall \exists} D$, where $D$ is the semantic model of the fragment $F$. $F^{0}$ has a model $M$, each element that satisfies one of the formulas $\varphi(x)$ of data by condition (2). Due to the convexity of $F$, this $M$ model is a nuclear model of the $F$ fragment. Further, since $F$ is a perfect and existentially simple theory $M$ is an existentially closed model of the center $F^{*}$ and by virtue of convexity, it is unique.

\title{
References
}

1 Vaught, R. (1961). Denumerable models of complete theories in Infinitistic Methode, Pergamon. London.

2 Baldwin, J.T. \& Kueker, D.W. (1981). Algebraically prime models. Ann. Math. Logic., 20, $289-330$.

3 Kueker, D.W. (1973). Core structures for theories. Fundamental Mathematicae LXXXIX, $154-171$.

4 Yeshkeyev, A.R., \& Issaeva, A.K. (2019). $\nabla$-cl - atomic and prime sets. Bulletin of the Karaganda University. Mathematics series, Vol. 93, 1, 88-94. DOI 10.31489/2019M1/88-94

5 Yeshkeyev, A.R., Issaeva, A.K. \& Mussina, N.M. (2019). The atomic definable subsets of semantic model. Bulletin of the Karaganda University. Mathematics series, Vol. 94, 2, 84-91. DOI 10.31489/2019M2/84-91

6 Yeshkeyev, A.R. (2015). The properties of similarity for Jonsson's theories and their models. Bulletin of the Karaganda University. Mathematics series, Vol. 80, 4, 52-59.

7 Yeshkeyev, A.R. (2017). Companions of the fragments in the Jonsson enrichment. Bulletin of the Karaganda University. Mathematics series, Vol. 85, 1, 41-45.

8 Yeshkeyev, A.R., \& Ulbrikht, O.I. (2019). JSp-cosemanticness of R-modules. Siberian electronics mathematical reports, Vol. 16, 3, 1233-1244. Retrieved from https://doi.org/10.33048/semi.2019.16.084

9 Yeshkeyev, A.R. (2016). Existential prime convex Jonsson theories and their models. Bulletin of the Karaganda University. Mathematics series, Vol. 81, 1, 41-45.

\author{
А.Р. Ешкеев, А.Қ. Исаева, Н.В. Попова
}

\section{Семантикалық модельдің арнайы атомдық анықталған ішкі жиындарының тұйықтамасы}

\begin{abstract}
Мақалада жалпы айтқанда, теориялардың, яғни толық теория болуы міндетті емес, кішігірім модельдерінің нақты қасиеттері және олардың өзара байланысы қарастырылған. Саналымды тілдегі атомдық модельдер саналымды жай модельдер үшін фундаменталды теореманың белгілі критерий тәртібін Р. Воот [1] жұмысында дәлелдеді. Бұл критерийдің мағынасы, яғни толық теорияның кез келген моделі осы теорияның саналымды жәй саны біруақытта атомдық моделі болып табылады. Осы жұмыстағы алынған негізгі нәтиже неғұрлым жалпы есеп қойылымы тұрғысынан қарағанда толық теориялардың саналымды-жай модельдер үшін Вооттың классикалық есебімен байланысты. Ұсынылып отырған жұмыстың мақсаты қандай да бір йонсондық теориялардың семантикалық моделінің фрагментінің арнайы ішкі жиындарының синтаксистік қасиеттеріне бағытталған. Сонымен қатар, йонсондық теория аясында атомдық ұғымдарын нақтылауға қатысты нәтижелерді алу үшін модельді-теоретикалық реостат ұғымы қолданылады.
\end{abstract}

Kiлm сөздер: йонсондық теория, семантикалық модель, экзистенциалды жай модель, атомдық модель, ядролық модель. 


\section{А.Р. Ешкеев, А.К. Исаева, Н.В. Попова \\ Замыкание специальных атомных подмножеств семантической модели}

Статья касается некоторых свойств так называемых малых моделей, вообще говоря, не обязательно полных теорий и их взаимосвязи друг с другом. В работе [1] Р. Воот доказал фундаментальную теорему-критерий поведения счетных простых и атомных моделей для полных теорий на счетном языке. Суть критерия заключается в том, что в полной теории любая модель счетного простого числа является одновременно атомной. Результат, полученный авторами статьи, связан с классической проблемой Воота о счетно простых моделях полных теорий, но в более общей формулировке понятия счетной атомности. Главным моментом этой статьи является то, что она фокусируется на синтаксических свойствах специальных подмножеств фрагмента семантической модели конкретной теории Йонсона. Концепция так называемого теоретико-модельного «реостата» была также использована для получения результатов, связанных с уточнением концепции атомности в рамках теорий Йонсона.

Ключевые слова: йонсоновская теория, семантическая модель, экзистенциально простая модель, атомная модель, ядерная модель. 